\title{
Consumption of Iron-Rich Foods by Teenage Students In Owo, Nigeria
}

\author{
\#Koleosho A.T., Akinrinmade R., *Uloko Mabel E., Ehinola O.M., and \\ Roland-Ayodele M.A. \\ Department of Nutrition and Dietetics, Rufus Giwa Polytechnic, PMB 1019, Owo, Ondo State, Nigeria. \\ *Department of Home Economics, Federal College of Education (Tech), Asaba, Delta State, Nigeria.
}

\begin{abstract}
This study was carried out to find out the consumption of iron-rich foods by teenage students and to know their nutritional status. A total of 120 students were randomly selected from four secondary (2 private and 2 government) schools, i.e. 30 students from each school. A structured questionnaire was used to obtain data from the students. Anthropometric measurements of the students were taken using the standard techniques described by World Health Organization ${ }^{(20)}$. Weights were recorded to the nearest $0.1 \mathrm{~kg}$ using a standard bathroom scale; and their height were measured to the nearest $0.1 \mathrm{~cm}$ with the use of a standard tape rule. The result revealed that $41.7 \%$ (50) of the respondents were males, $58.3 \%(70)$ were females. The result also showed that $94.2 \%$ of the respondents were in good health, $23.3 \%$ had some knowledge about anaemia; $5 \%$ had taken blood transfusion, $67.5 \%$ usually take iron supplements while $32.5 \%$ do not. The anthropometric parameter showed that $26.7 \%$ of the respondents were underweight, $65 \%$ had normal weight and $8.3 \%$ were overweight in private schools; while 53.3\% were underweight, $41.7 \%$ had normal weight and $5 \%$ were overweight for the government schools. It was observed that many of the students (53.3\%) from the government schools had lower BMI, compared to that of students (26.7\%) from the private schools; which implies that the students from the private secondary schools are better nourished than those from the government schools. As regarding iron-rich foods, $31.7 \%$ of the respondents eat vegetables $(3.8 \mathrm{mg} / 100 \mathrm{~g})$ three times daily, $23.3 \%$ eat meat $(3.1 \mathrm{mg} / 100 \mathrm{~g}$ ) thrice daily, and $15.8 \%$ eat legumes $(5.0 \mathrm{mg} / 100 \mathrm{~g})$ thrice daily. Generally, we conclude that their diet is adequate in iron nutrient; being that they consume vegetables, fish, meat, cereals and legumes several times per day. We recommend that they take more meat, fish and poultry (chicken) because the body absorbs the most iron from these foods, and prevents the incidence of anaemia.

Key words: Iron, Anaemia, Teenage, Anthropometry, Nutritional Status
\end{abstract}

\section{Introduction}

Iron is an essential micronutrient because it plays a vital role in oxygen transport, oxidative metabolism, cellular proliferation and many other physiological processes and it is a redox metal and participates in most of the reversible one-electron oxidation-reduction reactions by switching between the two oxidation states, ferrous and ferric ${ }^{(2)}$. This redox activity of iron can produce free radicals responsible for cell signaling processes and iron mediated toxicity. Iron is also an essential mineral for all known pathogens, because of which may have developed complex mechanism for iron acquisition and proliferation in an iron restricted environment ${ }^{(11)}$. The human body has therefore developed intricate but exquisitely controlled mechanism to absorb, transport and store iron, thus ensuring a ready supply for cellular growth and functions, but limiting its participation in reactions that produce free radicals and availability to invading pathogens ${ }^{(14)}$.

However, anaemia is wide spread inspite of diversity in food habits, particularly in the consumption of cereals and such tight metabolic regulation ${ }^{(18)}$. The casualty between poor dietary iron density, bioavailability and high prevalence of anaemia in our population has not been well established as anaemia has a multi-factorial aetiology ${ }^{(17)}$. Iron deficiency anaemia in a population results in consequences that have serious implications and it is now recognized that even mild-to-moderate anaemia can lead to lowered national productivity ${ }^{(18)}$. According to $\mathrm{WHO}^{(20)}$, anaemia is defined as a condition in which there is low level of haemoglobin in the blood either because there are few red blood cells and/or little haemoglobin in each cell. There are many different types of anaemia, but iron deficiency anaemia is the most common type ${ }^{(16)}$.

The Dietary Reference Intake (DRI) ${ }^{(13)}$ of iron for male and female adolescents are: For males 9-13 years $(8 \mathrm{mg} /$ day), $14-18$ years $(11 \mathrm{mg} /$ day $), 19-30$ years $(8 \mathrm{mg} /$ day). For females $9-13$ years $(8 \mathrm{mg} /$ day $), 14-18$ years $\left(15 \mathrm{mg} /\right.$ day), $19-30$ years $(15 \mathrm{mg} /$ day $) .{ }^{(2)}$.

It is estimated that around 2.15 billion individuals suffer from iron deficiency anaemia ${ }^{(16)}$. The risk of anaemia appears as early as childhood for both boys and girls ${ }^{(1)}$ after which subsides for boys but remains for girls because of menstrual blood loss.

Adolescence is the transition period between childhood and adulthood, a time of life that begins at puberty. Secondary school students are grouped or known to be adolescents. For girls, puberty typically occurs 
between ages 12 and 13, while for boys, it occurs between 14 and 15 years. It is one of the fastest growth periods of a person's life. During this time, physical changes affect the body's nutritional needs, while changes in one's lifestyle may affect eating habits and food choices.

Nutritional health during adolescence is important for supporting the growing body and for preventing future health problems ${ }^{(4)}$. The physical changes of adolescence have a direct influence on a person's nutritional needs. Teenagers therefore need additional calories, protein, calcium and iron. As adolescents gain muscle mass, more iron is needed to help their new muscle cells obtain oxygen for energy. A deficiency of iron causes anaemia which leads to fatigue, confusion and weakness. Adolescent boys need 12 milligrams of iron each day, while girls need 15 milligrams ${ }^{(6)}$. Good sources of iron include beef, chicken, pork, legumes including beans and peanut, enriched or whole grains and leafy vegetables such as spinach, collards and kale ${ }^{(5)}$. Nutritional status is the balance between the intake of nutrients by an organism and the expenditure of these in the processes of growth, reproduction and health maintenance.

Iron status can be considered as a continuum from iron deficiency with anaemia, to iron deficiency with no anaemia, to normal iron status with varying amounts of stored iron and finally to iron overload, which can cause organ damage when severe ${ }^{(10)}$. Iron deficiency is the result of long-term negative iron balance. Iron stores in the form of haemosiderin and ferritin are progressively diminished and no longer meet the needs of normal iron turnover. From this critical point onward, the supply of iron to the transport protein apotransperin is compromised ${ }^{(12)}$. This condition results in a decrease in transferring saturation and an increase in transferring receptors in the circulation and on the surface of cells, including the erythron. All tissues express their need for iron in exactly the same way, i.e. by the same type of transperin receptors on cell surface as in proportion to actual iron needed. Accordingly, a compromised supply of iron to the erythron is associated with a similar insufficient supply of iron to all other tissues ${ }^{(8)}$.

Iron deficiency is defined as a condition in which there are no mobilizable iron stores and in which signs of a compromised supply of iron to tissues, including the erythron are noted. The more severe stages of iron deficiency are associated with anaemia ${ }^{(9)}$. When iron-deficiency occurs, haemoglobin concentrations are reduced to below-optimal levels. When the individual haemoglobin levels are below two standard deviations (2SD) of the distribution mean for haemoglobin in an otherwise normal population of the same gender and age who are living at the same altitude, iron deficiency anaemia is considered to be present.

An iron-rich diet is a diet that includes rich sources of iron each day. People need to follow an iron-rich diet to treat or prevent a low blood iron level. People need extra iron during childhood, adolescence (teenage years), and pregnancy. Iron is a mineral the body needs to make hemoglobin ${ }^{(19)}$. Hemoglobin helps carry oxygen from your lungs to the rest of your body. A low blood iron level may be caused by not getting enough iron from food or by losing blood. If you do not have enough iron in your blood, you may get iron deficiency anemia. Iron deficiency anemia may cause problems with a child's growth and development, and cause other health problems in adults.

Meat, fish, poultry: The body absorbs the most iron from meat, fish and poultry (chicken). The amount of iron, in milligrams (mg), that is found in these foods is listed below:

- Very good sources (3.5 mg or more per serving) ${ }^{(19)}$ :

o Three ounces of beef or chicken liver.

o Three ounces of clams or mollusks.

o Three ounces of oysters.

- Good sources (2.1 mg or more per serving):

o Three ounces of cooked beef (ground or steak).

o Three ounces of canned sardines (canned in oil).

o Three ounces of cooked turkey.

- Other sources ( $0.7 \mathrm{mg}$ or more per serving):

o Three ounces of chicken.

o Three ounces of halibut, haddock, perch, salmon, and tuna.

o Three ounces of pork (ham).

o Three ounces of veal.

Other iron-rich foods: Other foods also contain iron, but your body does not absorb the iron from these foods as well. To increase iron absorption from the following foods, eat a good source of Vitamin $\mathbf{C}$ at the same time. Eating a food from the meat, fish, and poultry group at the same time will also increase iron absorption ${ }^{(19)}$. The amount of iron that is found in these foods is listed below:

- Very good sources (3.5 mg or more) ${ }^{(19)}$ :

o Breakfast cereals enriched with iron.

o One cup of cooked beans (white beans, soybeans, lentils or chickpeas).

o One ounce of pumpkin, sesame, or squash seeds. 
This study aims to reveal the consumption pattern of iron-rich foods by teenage students, with a view to help reduce the incidence of anaemia in private and public schools.

\section{Methodology}

The study was carried out in Owo township of Ondo State, Nigeria. Owo has a federal medical centre, saw mill, hospitality industry, banking sectors, primary, secondary and tertiary institutions, as well as many men and women who engage in business activities in the township market.

A structured questionnaire was used to obtain data from four secondary schools, two private and two government. Permission was first taken from the school authority to distribute the questionnaires to the students. Other instruments used to collect data were standard bathroom scale for measuring weight, and heightometer for measuring height.

Random sampling was used to select 120 students from the 4 schools combined. 30 students from each school from JSS 1 to SS 3 were involved in the study, randomly selecting five students from each class for the study.

Anthropometric measurement (heights and weights) of the students were taken using the standard techniques described by World Health Organization ${ }^{(20)}$. Weights were recorded to the nearest $0.1 \mathrm{~kg}$ using a standard bathroom scale; and their heights were measured to the nearest $0.1 \mathrm{~cm}$ with the use of a standard tape rule.

The body mass index $(\mathrm{BMI})=$ weight $(\mathrm{kg}) / \mathrm{height}^{2}\left(\mathrm{~m}^{2}\right)$ i.e. $\mathrm{kg} / \mathrm{m}^{2}$ was calculated. BMI was used to determine their nutritional status. The BMI reference of $\mathrm{WHO}^{(20)}$ was used to classify the students as either underweight, normal, overweight or obese. BMI below 18.5 is considered underweight, from 18.5 to 24.9 is normal, 25.0 to 29.9 is overweight and 30.0 above is obese.

The questionnaires were analyzed using Statistical Package for Social Sciences (SPSS15) software. Descriptive statistics such as frequencies, and percentage were determined.

\section{Results}

Table 1: Demographic data of the respondents

\begin{tabular}{lll}
\hline Variable & Frequency & Percentage (\%) \\
\hline Type of School & & \\
Private & 60 & 50 \\
Government & 60 & 50 \\
Sex & & \\
Male & 50 & 41.7 \\
Female & 70 & 58.3 \\
Age & & \\
$10-14$ & 52 & 43.3 \\
$15-19$ & 68 & 56.7 \\
& \\
\hline
\end{tabular}

Table 1 shows that $41.7 \%$ (50) of the respondents were male, while 58.3\% (70) were female. Also 50\% of the respondents were from private schools, while $50 \%$ were from government schools. $43.3 \%$ were younger teenagers, while $56.7 \%$ were older teenagers.

Table 2: Health status of the students

\begin{tabular}{lll}
\hline Subject (Variable) & Frequency & Percentage\% \\
\cline { 2 - 3 } In Good Health & 113 & 94.2 \\
Yes & 7 & 5.8 \\
No & & \\
Awareness of Iron & 28 & 23.3 \\
deficiency anaemia & 92 & 76.7 \\
Yes & & \\
No & 6 & 5 \\
Taken blood transfusion & 114 & 95 \\
before & & \\
Yes & 81 & 67.5 \\
No & 39 & 32.5 \\
& \\
Iron supplementation & & \\
Yes & & \\
No & &
\end{tabular}


Table 2 above shows that $94.2 \%$ of the respondents were in good health, $5.8 \%$ were not in good health. Also, $23.3 \%$ of the respondents were aware of anaemia, while $76.7 \%$ were not aware of iron deficiency anaemia.

The results showed that $5 \%$ of the respondents had taken blood transfusion before, while $95 \%$ never did. It was revealed that $67.5 \%$ of the respondents usually take iron supplements, while $32.5 \%$ do not.

Table 3: Anthropometric Parameters of the Students in Private Schools

\begin{tabular}{lll}
\hline Students & Frequency & Percentage \% \\
\hline Underweight & 16 & 26.7 \\
BMI $<18.5$ & & \\
$\begin{array}{l}\text { Normal weight } \\
\text { BMI 18.5-24.9 }\end{array}$ & 39 & 65.0 \\
$\begin{array}{l}\text { Overweight } \\
\text { BMI 25-29.9 }\end{array}$ & 5 & 8.3 \\
Total & 60 & 100 \\
\hline
\end{tabular}

Table 3 shows the nutritional status of the respondents as $26.7 \%$ being underweight, $65 \%$ had normal weight, and $8.3 \%$ were overweight.

Table 4: Anthropometric Parameters of Students in Government Schools

\begin{tabular}{lll}
\hline Students & Frequency & Percentage \% \\
\hline $\begin{array}{l}\text { Underweight } \\
\text { BMI<18.5 }\end{array}$ & 32 & 53.3 \\
$\begin{array}{l}\text { Normal weight } \\
\text { BMI 18.5-24.9 }\end{array}$ & 25 & 41.7 \\
$\begin{array}{l}\text { Overweight } \\
\text { BMI 25-29.9 }\end{array}$ & 3 & \\
Total & 60 & 5.0 \\
\hline
\end{tabular}

Table 4 shows the nutritional status of the respondents as $53.3 \%$ being underweight, $41.7 \%$ of them had normal weight, while $5 \%$ were overweight.

Table 5: Iron-rich food consumption frequency (daily)

\begin{tabular}{|c|c|c|c|c|c|c|c|c|c|}
\hline \multirow[t]{3}{*}{ Food Items } & \multirow{3}{*}{$\begin{array}{l}\text { *Amount of } \\
\text { Fe per } 100 \mathrm{~g} \\
(\mathrm{mg})\end{array}$} & \multicolumn{6}{|c|}{ Frequency of Consumption, Daily } & \\
\hline & & Once & & Twice & & Thrice & & Others & \\
\hline & & Freq & $\%$ & Freq & $\%$ & Freq & $\%$ & Freq & $\%$ \\
\hline $\begin{array}{l}\text { Vegetables } \\
\text { (spinach) }\end{array}$ & 3.8 & 46 & 38.3 & 33 & 27.5 & 38 & 31.7 & 3 & 2.5 \\
\hline Cereals(bread) & 1.3 & 52 & 43.4 & 37 & 30.8 & 31 & 25.8 & 0 & 0 \\
\hline Fish(sardine) & 2.4 & 24 & 20 & 56 & 46.7 & 40 & 33.3 & 0 & 0 \\
\hline Meat(beef) & 3.1 & 62 & 51.7 & 30 & 25 & 28 & 23.3 & 0 & 0 \\
\hline Legumes & 5.0 & 58 & 48.4 & 43 & 35.8 & 19 & 15.8 & 0 & 0 \\
\hline
\end{tabular}

*NutriSurvey, 2007

Table 5 shows that $31.7 \%$ of the respondents eat vegetables $(3.8 \mathrm{mg} / 100 \mathrm{~g})$ three times daily. $23.3 \%$ eat meat $(3.1 \mathrm{mg} / 100 \mathrm{~g})$ thrice daily. $15.8 \%$ eat legumes, a rich source of iron $(5.0 \mathrm{mg} / 100 \mathrm{~g})$ thrice daily. The foods are prepared in a variety of ways to limit monotony.

\section{Discussion}

This study was carried out to find out the consumption pattern of iron-rich foods by teenage students and to know their nutritional status. Findings show that $41.7 \%$ (50) (table 1) of the respondents were male, while $58.3 \%$ (70) were female.

The study shows that $94.2 \%$ (table 2) of the respondents were in good health, $5.8 \%$ were not in good health. It was discovered that $23.3 \%$ of the respondents were aware of anaemia, while $76.7 \%$ were not aware of iron deficiency anaemia. In a similar work done by Onyechi and Nkwuaku ${ }^{(15)}$ findings showed that $41 \%$ of the subjects actually suffered from anaemia; but that was not the case in this study. Among the subjects 5\% had taken blood transfusion before, while $95 \%$ never did. Also noted, 67.5\% of the respondents take iron supplements, while $32.5 \%$ do not.

Looking at the nutritional status of the subjects (table 3) in the two private schools, $26.7 \%$ were underweight, $65 \%$ have normal weight, and $8.3 \%$ were overweight. Closely followed by the nutritional status of 
the subjects in the two government schools (table 4), 53.3\% were underweight, $41.7 \%$ of them have normal weight, while $5 \%$ were overweight. The private schools had fewer underweight $(26.7 \%)$, more overweight $(8.3 \%)$ and many normal $(65.0 \%)$ students. But the public schools had more underweight $(53.3 \%)$, fewer overweight $(5.0 \%)$ and some normal $(41.7 \%)$ students with regards to their nutritional status. This is similar to the work done by Dey et al ${ }^{(7)}$, using 420 participants (39\% girls) they found that $40 \%$ of the adolescents were undernourished. Severe malnutrition was found in $27 \%$ of male and $29 \%$ of female population; while $44 \%$ of the study participants were stunted and $14 \%$ were severely stunted ${ }^{(7)}$.

Pertaining to iron-rich foods, $31.7 \%$ of the respondents eat vegetables $(3.8 \mathrm{mg} / 100 \mathrm{~g})$ three times daily, $23.3 \%$ eat meat $(3.1 \mathrm{mg} / 100 \mathrm{~g})$ thrice daily, $15.8 \%$ eat legumes $(5.0 \mathrm{mg} / 100 \mathrm{~g})$ thrice daily. A study by Awobajo et $a l,{ }^{(3)}$ showed that Telfaria occidentalis, a vegetable, reduces the incidence of anaemia. In this study, spinach is also a good agent in reducing the incidence of anaemia.

Majority (43.4\%) of the respondents take cereals only once daily, $30.8 \%$ eat cereals twice daily, $25.8 \%$ eat cereals thrice daily. This may imply that students have access to other foods outside the school menu time table. Several (20\%) of the respondents take fish once daily, $46.7 \%$ take fish twice, while $33.3 \%$ take fish thrice daily. There were some (51.7\%) of the respondents who eat meats only once daily, $25 \%$ eat twice, while $23.3 \%$ eat thrice daily. The consumption of legumes like beans, groundnut was done once (48\%) daily, $35.8 \%$ eat legumes twice daily, and15.8\% eat legumes thrice daily. Legumes happen to be a rich source of dietary iron.

\section{Conclusion}

After some work on consumption of iron-rich foods by teenage students, we conclude that their diet is adequate in the mentioned nutrient; being that they consume vegetables, fish, meat, cereals and legumes several times per day. We recommend that they take more meat, fish and poultry (chicken) because the body absorbs the most iron from these foods. And we encourage the mass media (newspaper, radio, television, magazine) to broadcast more programs on nutrition and health, to enlighten our children and society on how to prevent and stay safe from diseases.

\section{References}

[1] Alleyne M, Horne MK, Miller JL (2008). Individualized treatment for iron-deficiency anemia in adults. Am J Med. 121:943-948.

[2] Ascherio, A., et al (1994). Dietary iron intake and risk of coronary disease among men. Circulation 89:969.

[3] Awobajo F.O., Olatunji-Bello I.I., Obilade T.T. and Odugbemi T.O. (2010). Knowledge of the Nutritional and Medicinal Use of Some Vegetables among a Cross Section of Market Women in Two Major Food Markets in Lagos State. Pakistan Journal of Nutrition 9 (3): 216-221

[4] Brady PG (2007). "Iron deficiency anemia: a call for". South. Med. J. 100 (10): 966-7.

[5] Brittenham G. (2008). Disorders of Iron Metabolism: Iron Deficiency and Iron Overload. In: Hoffman R, Benz EJ, Shattil SS, et al, eds. Hematology: Basic Principles and Practice. 5th ed. Philadelphia, Pa: Elsevier Churchill Livingstone; :chap 36.

[6] Calis JC, Phiri KS, Faragher EB, et al. (2008). "Severe anemia in Malawian children". N. Engl. J. Med. 358 (9): $888-99$.

[7] Dey I, Biswas R, Ray K, Bhattacherjee S, Chakraborty M, and Pal PP (2011). Nutritional status of school going adolescents in a rural block of Darjeeling, West Bengal, India: Department of Community Medicine, NRS Medical College \& Hospital, Kolkata, West Bengal, India. The Health, 2(3):75-77

[8] Harper JL et al (2011), Iron Deficiency Anemia, Medscape, Nov 2011

[9] Higdon J. (2006). Iron. Linus Pauling Institute Micronutrient Information Center.

[10] Lecos, Chris. (1983). Tracking Trace Minerals. FDA Consumer, July-Aug. 1983.

[11] Lynch, S. R. (1994). Overview of the relationship of iron to health. Contemporary Nutrition 19:4-5.

[12] Mazza J., Barr R. M., McDonald J.W., and Valberg L.S. (1978). "Usefulness of the serum ferritin concentration in the detection of iron deficiency in a general hospital". Canadian Medical Association Journal 119 (8): 884-886.

[13] National Academy of Sciences. (2001). Dietary Reference Intakes. Washington, D.C.: National Academy Press.

[14] National Institute of Health (2009). "Dietary Supplement Fact Sheet: Iron". United States of America, Department of Health and Human Services. Retrieved 2009-03-30.

[15] Onyechi U.A. and Nkwuaku O.A. (2011). Prevalence of Iron Deficiency Anaemia among pregnant women receiving antenatal care in Nsukka Urban Community, Nigeria. Journal of Dietitians Association of Nigeria, page 9.

[16] Pasricha SR, Flecknoe-Brown SC, Allen KJ, et al (2010); Diagnosis and management of iron deficiency anaemia: a clinical update. Med J Aust. Nov 1;193(9):525-32. [abstract]

[17] Salonen, J.T., et al. (1992). High stored iron levels are associated with excess risk of myocardial infarction in Eastern Finnish men. Circulation, 86:3.

[18] Shils, M.S., Olson J.A., Shike M. (1994). Iron in medicine and nutrition. Modern Nutrition and Health and Disease. 8th Edition. Philadelphia, Lea and Fbiger. pp. 185-213.

[19] Thomson (2006). Iron Rich Diet, Thomson MICROMEDEX; pp.1-2

[20] WHO (2004). Assessing the iron status of populations World Health Organization Department of Nutrition for Health and Development, Centers for Disease Control and Prevention Division of Nutrition and Physical Activity. 